\title{
Spectroscopic investigation and density functional theory calculations of mercaptobenzothiazole and mercaptobenzimidazole ligands and their rhenium complexes
}

\author{
Noura AlHokbany ${ }^{*}$, Ibrahim AlJammaz ${ }^{2}$ \\ ${ }^{1 *}$ Department of chemistry, College of Science, King Saud University, Riyadh, Kingdom of Saudi Arabia; \\ ${ }^{2}$ Cyclotron and Radiopharmaceuticals Department, King Faisal Specialist Hospital and Research Center, Riyadh, Kingdom of Saudi \\ Arabia \\ Email: nhokbany@ksu.edu.sa
}

Received 22 April 2011; revised 1 July 2011; accepted 11 July 2011.

\begin{abstract}
Four complexes containing the $[\operatorname{Re}(\mathrm{V}) \mathrm{O}]^{3+}$ core have been prepared by substitution on the precursors $\mathrm{RO}(\text { citrate })_{2}{ }^{-}$and $\mathrm{ReO}$ (gluconate $)_{2}{ }^{-}$. The complex $\left[\mathrm{ReO}(\mathrm{MBT})_{2} \mathrm{OH}\right]$ was obtained by reaction of the direct reduction of $\mathrm{ReO}_{4}^{-}$using sodium borohydride as a reducing agent. Four complexes were characterized by UV-Vis and IR spectrophotometer, elemental analyses, ${ }^{1} \mathrm{H}$-and ${ }^{13} \mathrm{C}$ NMR spectroscopy, TG and DFT calculations.
\end{abstract}

Keywords: $[\mathrm{ReO}]^{3+}$, DFT, Mercaptobenzothiazole Ligand, Mercaptobenzimidazol Ligand, TG/DTA, XPS, Rhenium Complexes.

\section{INTRODUCTION}

Heterocyclic thiolates are electron-rich and multifunctional ligands, that show various coordination modes and form monomeric or polymeric complexes [1]. They can act as unidentate or bidentate ligands in metal complexes.

Mercapto-1,3-azole ligands play an important role in industry and medicine [2]. One of their attractive features is their acidity, which could influence their chemical reactivity toward transition metal ions and determine the structure of the final complexes. These small molecules exist as two tautomeric conformations exhibiting thiolthione isomerism involving $-\mathrm{NH}-\mathrm{C}=\mathrm{S}$ and $-\mathrm{N}=\mathrm{C}-\mathrm{SH}$ groups in a thione-thiol equilibrium [3].

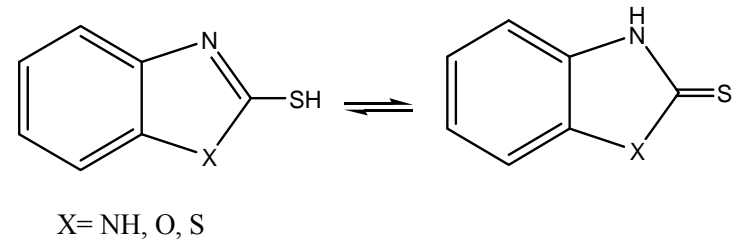

Probably, only two atoms can act as bonding sites; the sulfur exocyclic atom and the cyclic nitrogen atom. Because the lone pairs on the oxygen or sulfur atoms are involved in the resonating structures of the molecules, we may expect that they should have no coordinating abilities. To investigate this and as part of our research into rhenium ( $R e$ ) chemistry, we decided to investigate the chemical behavior of ambidentate ligands such as 2-mercaptoben-zothiazole (MBT) and 2-mercaptobenzimidazole (Bimz).

The coordination chemistry of Re has been explored because of its use in radiopharmaceuticals. Rhenium radiopharmaceuticals are a class of therapeutic agents in which the biodistribution is determined by the size, charge and lipophilicity of the complex. Among these compounds, the chemistry of oxo rhenium complexes is of particular interest. The interesting chemistry results from the favorable nuclear properties of ${ }^{186} \mathrm{Re}$ and ${ }^{188} \mathrm{Re}$ nuclides, which make the radioisotopes useful for diagnostic nuclear medicine and applications in radioimmunotherapy [4]. Our aim was to study the chemical properties of mercaptobenzothiazole ligands toward the $[\mathrm{Re}=\mathrm{O}]^{3+}$ core. In this paper, we describe the synthesis of oxorhenium complexes and the characterization of those complexes with several spectroscopic methods. In addition, density functional theory (DFT) calculations of some representative compounds are also discussed.

\section{EXPERIMENTAL}

\subsection{Materials and Methods}

All the reagents used to the synthesis were commercially available and were used without further purification. $\mathrm{ReO}$ (citrate) $)_{2}^{-}$and $\mathrm{ReO}$ (gluconate) ${ }_{2}{ }_{2}^{-}$precursors were prepared according to literature $[5,6]$ respectively. IR spectroscopy was recorded on a Perkin Elmer spectro- 
photometer 1000 in the spectral range $200-4000 \mathrm{~cm}^{-1}$ with sample in the form of $\mathrm{KBr}$ pellets. UV-Vis spectra were recorded on UV-Vis Beckman Du-70 spectrophotometer in the range $190-700 \mathrm{~nm} .{ }^{1} \mathrm{H}-{ }^{13} \mathrm{C}$ NMR spectra were measured in (DMSO- $\mathrm{d}_{6}$ and $\mathrm{CDCl}_{3}$ ) as solvents on a JOEL-NMR $400 \mathrm{MHz}$ spectrometer. Micro-analytical (CHN) were run at the Mikronalytisches Labor Pascher, Germany. Thermogravimetric/differential Thermal analysis (TG/DTA) measurements were carried out using Perkin- Elmer TG A7 thermal analyzer, the weight loss was measured from ambient temperature up to $1000^{\circ} \mathrm{C}$ at a heating rate of $10^{\circ} \mathrm{C} / \mathrm{min}$. About $15 \mathrm{mg}$ of the compound was used for the analysis, with alumina as the reference material. Mass spectroscopy was run on Quattra Gas chromatography mass spectrometer run at the Mikronalytisches Labor Pascher, Germany.

\subsection{Synthesis of Complexes}

\subsection{1. $\left[\mathrm{ReO}_{2}(\mathrm{MBT})\left(\mathrm{H}_{2} \mathrm{O}\right)_{2}\right] \mathrm{I}$}

$\mathrm{NaReO}_{4}(1 \mathrm{mmol}, 0.273 \mathrm{~g})$ was added to a solution of $\mathrm{SnCl}_{2}(1 \mathrm{mmol}, 0.256 \mathrm{~g})$ in citric acid $(0.5 \mathrm{M}, 5 \mathrm{~mL})$. MBT ( $3 \mathrm{mmol}, 0.501 \mathrm{~g}$ ) in ethanol was added dropwise to the mixture. The mixture was stirred at room temperature for $3 \mathrm{hr}$. The $\mathrm{pH}$ was adjusted to 9 with $\mathrm{NaOH}(0.5 \mathrm{M})$ [6]. The blackgreen precipitate was filtrated and washed with ethanol and acetone to obtain green crystals, (89\% yield) of compound: UV-Vis $\left(\mathrm{CH}_{2} \mathrm{Cl}_{2}\right) ; \lambda_{\max }[\mathrm{nm}]\left(\varepsilon ; \mathrm{dm}^{3} \mathrm{~mol}^{-1} \mathrm{~cm}^{-1}\right)$ : 205(1582), 219(1044), 355 (1499). ${ }^{1} \mathrm{H}$ NMR (d6-DMSO, ppm): $7.7(\mathrm{~m}, \mathrm{Ha}, \mathrm{Hc}), \quad 7.4(\mathrm{~m}, \mathrm{Hb}), \quad 7.2(\mathrm{~m}, \mathrm{Hd})$ ring. ${ }^{13} \mathrm{C}$ NMR $\left(\mathrm{CDCl}_{3}, \mathrm{ppm}\right): 122,123,126,127(\mathrm{C}=\mathrm{C}), 133(\mathrm{C}=$ C-C $-\mathrm{S}), 189(\mathrm{~S}=\mathrm{C}), 141(\mathrm{C}=\mathrm{C}-\underline{\mathrm{C}}-\mathrm{N}) . \quad \mathrm{IR}\left(\mathrm{KBr}, \mathrm{v} / \mathrm{cm}^{-1}\right)$ : 914, $860(\mathrm{O}=\mathrm{Re}=\mathrm{O}), 624(\mathrm{Re}-\mathrm{N}), 569(\mathrm{Re}-\mathrm{S}) . \mathrm{MS}(\mathrm{m} / \mathrm{z})$ : $420[\mathrm{M}]^{+}$.Anal.Calc. (Found) for $\mathrm{C}_{7} \mathrm{H}_{8} \mathrm{~S}_{2} \mathrm{NO}_{4} \mathrm{Re}$ : C, 20 . (19.97); H, 1.9 (1.78); N, 3.33 (3.01); Re, 44.3(42.2)\%.

\subsection{2. $\left[\mathrm{ReO}_{2}(\mathrm{Bimz})\left(\mathrm{H}_{2} \mathrm{O}\right)_{2}\right]$ II}

$\mathrm{NaReO}_{4}(1 \mathrm{mmol}, 0.273 \mathrm{~g})$ was added to a solution of $\mathrm{SnCl}_{2}(1 \mathrm{mmol}, 0.2256 \mathrm{~g})$ in citric acid $(0.5 \mathrm{M}, 5 \mathrm{~mL})$. Followed by the dropwise addition of Bimz (3mmol, $0.45 \mathrm{gm})$ in $\mathrm{EtOH}$. The mixture was stirred at room temperature for $3 \mathrm{hr}$. The $\mathrm{pH}$ was adjusted to 9 with $\mathrm{NaOH}$ $(0.5 \mathrm{M})$. Filtration the blackgreen precipitate and washed with ethanol and acetone to obtain the yellow powder, $89.7 \%$ yield of compound: UV-vis $\left(\mathrm{CH}_{2} \mathrm{Cl}_{2} ; \lambda_{\max }[\mathrm{nm}]\right.$ $\left(\varepsilon ; \mathrm{dm}^{3} \mathrm{~mol}^{-1} \mathrm{~cm}^{-1}\right): 190(1911), 245(456) .{ }^{1} \mathrm{H}$ NMR (d6DMSO, ppm): 12.2(s, NH), 7.7(m, Ha, Hc), 7.4(m, Hb), 7.2(m,Hd) ring. ${ }^{13} \mathrm{C}$ NMR $\left(\mathrm{CDCl}_{3}, \mathrm{ppm}\right): 122,123,126$, $127(\mathrm{C}=\mathrm{C}), 133(\mathrm{C}=\mathrm{C}-\underline{\mathrm{C}}-\mathrm{S}), \quad 189(\mathrm{~S}=\mathrm{C}), 141(\mathrm{C}=\mathrm{C}-\underline{\mathrm{C}}-\mathrm{N})$. IR $\left(\mathrm{KBr}, \mathrm{v} / \mathrm{cm}^{-1}\right): 909,843(\mathrm{O}=\mathrm{Re}=\mathrm{O}), 618(\mathrm{Re}-\mathrm{N}), 547$ $(\operatorname{Re}-\mathrm{S})$. MS (m/z): 402[M] $]^{+}$. Anal. Calc. (found) for $\mathrm{C}_{7} \mathrm{H}_{8} \mathrm{SN}_{2} \mathrm{O}_{4} \mathrm{Re}: \mathrm{C}, 20.8(19.89) ; \mathrm{H}, 1.99$ (1.57); N, 6.9 (6.24); Re, 46.3 (44.7) \%.

\subsection{3. [ReO(Bimz)2OH] III}

Rhenium (V)(gluconate) ${ }_{2}^{-}(14.8 \mathrm{~mL}, 1 \mathrm{mmol})$ solution was adjusted to $\mathrm{pH} 10$ by $\mathrm{NaOH}(0.1 \mathrm{M})$ followed by addition of Bimz ( $3 \mathrm{mmol}, 0.450 \mathrm{~g}$ ) dissolved in $1 \mathrm{~mL}$ of methanol. After stirring for $1 \mathrm{hr}$, to the mixture was addition of methanol to precipitate. $89 \%$ yield of compound: UV-vis $\left(\mathrm{H}_{2} \mathrm{O} ; \lambda_{\max }[\mathrm{nm}]\left(\varepsilon ; \mathrm{dm}^{3} \mathrm{~mol}^{-1} \mathrm{~cm}^{-1}\right): 240(3000)\right.$, 325(2060). ${ }^{1} \mathrm{H}$ NMR (d6-DMSO, ppm) 7.1 (m, Hb), 7.1(m, $\mathrm{Hc}), 7.3$ (m,Hd), 7.6(m,Ha): ${ }^{13} \mathrm{C}$ NMR (DMSO, ppm): 112 $(\mathrm{C}=\mathrm{C}), 121(\mathrm{C}=\mathrm{C}-\mathrm{N}), 179(\mathrm{C}=\mathrm{N}) . \quad \mathrm{IR}\left(\mathrm{KBr}, \mathrm{v} / \mathrm{cm}^{-1}\right)$ : $908(\mathrm{Re}=\mathrm{O}), 619(\mathrm{Re}-\mathrm{N}), 415(\mathrm{Re}-\mathrm{O})$. Anal.Calc.(found) for $\mathrm{C}_{14} \mathrm{H}_{9} \mathrm{~N}_{4} \mathrm{O}_{2} \mathrm{~S}_{2}$ Re: $\mathrm{C}, 32.6(31.9) ; \mathrm{H}, 1.74(1.85) ; \mathrm{N}$, $10.86(9.76) \%$.

\subsection{4. $\left[\mathrm{ReO}(\mathrm{MBT})_{2} \mathrm{OH}\right] \mathrm{IV}$}

To a solution of $\mathrm{NaReO}_{4}(1 \mathrm{mmol}, 0.2731 \mathrm{~g})$, MBT (3 $\mathrm{mmol}, 0.501 \mathrm{~g}$ ) in methanol was dropwise added. The reducing agent $\mathrm{NaBH}_{4}(1 \mathrm{mmole})$ in $(0.1 \mathrm{KOH} \mathrm{pH} 8)$ was added and the color of solution changed to bronze. The mixture was stirred at reflux for $3 \mathrm{hr}$, followed by evaporation to almost dryness, the gray precipitate recrystallized by hot methanol [5]. $86 \%$ yield of compound: UV-vis $\left(\mathrm{CH}_{2} \mathrm{Cl}_{2} ; \lambda_{\max }[\mathrm{nm}]\left(\varepsilon ; \mathrm{dm}^{3} \mathrm{~mol}^{-1} \mathrm{~cm}^{-1}\right)\right.$ : 205(1582), sh 219( 1044), 355(1499). ${ }^{1} \mathrm{H}$ NMR (d6DMSO, ppm): 7.7(m, Ha, Hc), 7.4(m, Hb), 7.2(m, Hd) ring, $1.2(\mathrm{~s}, \mathrm{OH}) .{ }^{13} \mathrm{C}$ NMR (DMSO, ppm): 122,123 , $126,127(\mathrm{C}=\mathrm{C}), 190(\mathrm{~S}=\mathrm{C}), 141(\mathrm{C}=\mathrm{C}-\underline{\mathrm{C}}-\mathrm{N}) . \mathrm{IR}(\mathrm{KBr}$, $\left.\mathrm{v} / \mathrm{cm}^{-1}\right): 912(\mathrm{Re}=\mathrm{O}), 661(\mathrm{Re}-\mathrm{N}), 649(\mathrm{Re}-\mathrm{S}), 432$ (Re-O). MS (m/z): $570[\mathrm{M}]^{+}$. Anal. Calc. (found) for $\mathrm{C}_{14} \mathrm{H}_{12} \mathrm{~S}_{4} \mathrm{~N}_{2} \mathrm{O}_{2} \mathrm{Re}: \mathrm{C}, 29.3(29.12) ; \mathrm{H}, 2.09(2.28) ; \mathrm{N}$, 4.91(5.12); Re, 32.6(30.9)\%.

\section{RESULTS AND DISCUSSION}

\subsection{Computational Details}

The GAUSSIAN 03 program [7] was used in the calculations. The complexes were treated as open shell-system and no symmetry constraints were applied. Geometrical optimization of the investigated complex was carried out with Beck's three parameter exchange functional B3LYP using the Los Alamos LANL2DZ spilt-valence basis set $[8,9]$. A harmonic vibrational analysis was performed following the geometrical optimization of the complex at the same level of theory B3LYP and the same basis set [10]. An additional d function with exponent $\mathrm{a}=0.3811$ and an $\mathrm{f}$ function with exponent $\mathrm{a}=2.033$ on the rhenium atom were added. Natural bond orbital (NBO) calculations were performed with the NBO code [11] included in GAUSSIAN 03. The optimized geometry for various forms of the MBT molecule is shown in Figure 1. The two tautomeric forms of MBT were subjected to geometry optimization at B3LYP/6-31G** (Table 1). 

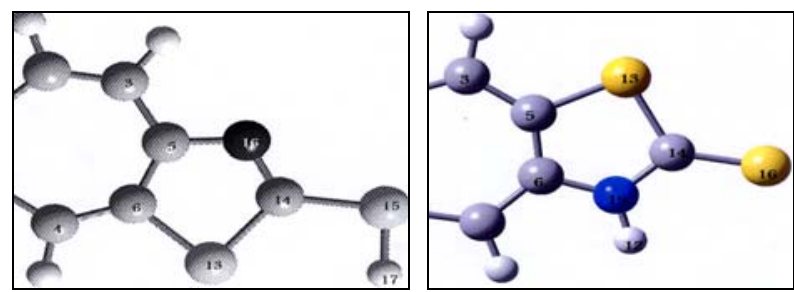

Figure. 1. Optimized geometry of MBT monomer in thiol(a) and thione (b) tatomeric equilibrium at B3LYP/6-31G**

Table 1.Selected optimized bond lengths $\left(\mathrm{A}^{\circ}\right)$ and angles $\left({ }^{\circ}\right)$ for MBT and Bimz ligands.

\begin{tabular}{ccc}
\hline Bond length $\left(\mathrm{A}^{\circ}\right)$ & Bond angles $\left(^{\circ}\right)$ & B3LYP/LANL2DZ \\
\hline MBT & & \\
$\mathrm{S}(15)-\mathrm{C}(14) 1.8159$ & $-\mathrm{S}(15)-\mathrm{C}(14) 17) \mathrm{H}($ & 96.102 \\
$\mathrm{~S}(15)-\mathrm{H}(17) 1.3784$ & $\mathrm{~S}(13)-\mathrm{C}(14)-\mathrm{N}(16)$ & 113.8972 \\
$\mathrm{C}(14)-\mathrm{N}(16) 1.2948$ & $\mathrm{~S}(13)-\mathrm{C}(5)-\mathrm{C}(6)$ & 109.04 \\
$\mathrm{~N}(16)-\mathrm{C}(6) 1.3918$ & $\mathrm{C}(14)-\mathrm{N}(16)-\mathrm{C}(6)$ & 114.22 \\
$\mathrm{C}(14)-\mathrm{S}(13) 1.8411$ & $\mathrm{C}(4)-\mathrm{C}(6)-\mathrm{N}(16)$ & 117.562 \\
Bimz & & \\
$\mathrm{C}(8)-\mathrm{S}(15) 1.812$ & $\mathrm{~N}(7)-\mathrm{C}(8)-\mathrm{N}(9)$ & 113.3 \\
$\mathrm{C}(8)-\mathrm{N}(9) 1.393$ & $\mathrm{C}(8)-\mathrm{S}(15)-\mathrm{H}(16)$ & 94.2 \\
$\mathrm{~N}(9)-\mathrm{H}(14) 1.010$ & $\mathrm{C}(8)-\mathrm{N}(9)-\mathrm{H}(14)$ & 126.2 \\
$\mathrm{~N}(7)-\mathrm{C}(8) 1.325$ & $\mathrm{~N}(9)-\mathrm{C}(8)-\mathrm{S}(15)$ & 120.7 \\
$\mathrm{~S}(15)-\mathrm{H}(16) 1.373$ & $\mathrm{C}(2)-\mathrm{N}(9)-\mathrm{H}(14)$ & 106.8 \\
\hline
\end{tabular}

\section{2. cis-dioxo $\left[\mathrm{ReO}_{2}(\mathrm{MBT})\left(\mathrm{H}_{2} \mathrm{O}\right)_{2}\right]$}

The most important bond lengths and angles for the compound are reported in Table 2. The transformation from the ideal octahedral to the distorted octahedral seen in complexes is mainly attributed to the electronic repulsion of the short $\mathrm{Re}=\mathrm{O}$ bond. For the $\left[\mathrm{ReO}_{2}(\mathrm{MBT})\right.$ $\left(\mathrm{H}_{2} \mathrm{O}\right)_{2}$ ] complex, the bridging N-S ligands introduce some additional strain (Figure 2).

The Re-N, $\mathrm{Re}=\mathrm{O}_{\text {terminal }}$ and Re-O bonds lengths in the

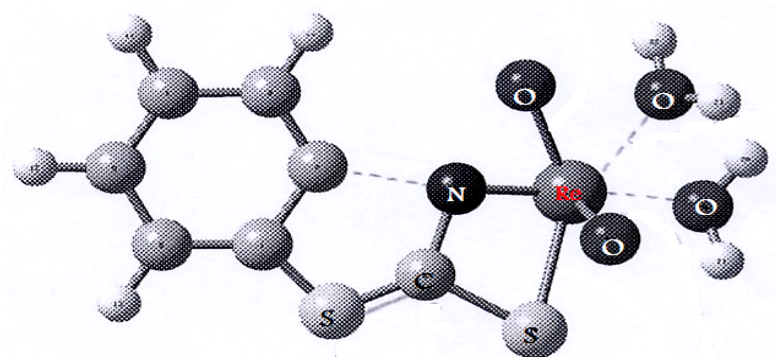

Figure 2. Optimized structure of $\left[\mathrm{ReO}_{2}(\mathrm{MBT})\left(\mathrm{H}_{2} \mathrm{O}\right)_{2}\right]$.

Table 2. Selected optimized bond lengths $\left(\mathrm{A}^{\circ}\right)$ and angles $\left({ }^{\circ}\right)$ for $\left[\mathrm{ReO}_{2}(\mathrm{MBT})\left(\mathrm{H}_{2} \mathrm{O}\right)_{2}\right]$

\begin{tabular}{ccc}
\hline Bond length (A $\left.{ }^{\circ}\right)$ & Bond angles ( $\left(^{\circ}\right)$ & B3LYP/LANL2DZ \\
\cline { 2 - 2 } $\operatorname{Re}(15)-\mathrm{O}(16) 2.0733$ & $\mathrm{O}(16)-\operatorname{Re}(15)-\mathrm{O}(17)$ & 159.9 \\
$\operatorname{Re}(15)-\mathrm{O}(17) 1.6954$ & $\mathrm{O}(17)-\operatorname{Re}(15)-\mathrm{N}(9)$ & 100.288 \\
$\operatorname{Re}(15)-\mathrm{N}(9) 2.1597$ & $\mathrm{~S}(14)-\operatorname{Re}(15)-\mathrm{N}(9)$ & 53.262 \\
$\operatorname{Re}(15)-\mathrm{S}(14) 3.3475$ & $\mathrm{~S}(14)-\operatorname{Re}(15)-\mathrm{O}(18)$ & 132.96 \\
$\operatorname{Re}(15)-\mathrm{O}(19) 2.094$ & $\mathrm{~N}(9)-\operatorname{Re}(15)-\mathrm{O}(19)$ & 156.40 \\
$\operatorname{Re}(15)-\mathrm{O}(18) 3.6705$ & $\mathrm{~N}(9)-\mathrm{C}(8)-\mathrm{S}(14)$ & 121.33 \\
\hline
\end{tabular}

$\left[\mathrm{ReO}_{2}(\mathrm{MBT})\left(\mathrm{H}_{2} \mathrm{O}\right)_{2}\right]$ complex agree with comparable values found in rhenium compounds with a $\mathrm{Re}=\mathrm{O}$ core $[13,14]$. The mean $\mathrm{Re}=\mathrm{O}_{\text {terminal }}$ bond lengths of 1.680 and $1.712 \AA$ correspond to the values reported for mononuclear mono-oxo $\mathrm{d}^{2}$ rhenium complexes with an average bond length of $1.70 \AA$ [15]. These results suggest that a small amount of overlap also occurs between the $d_{x z}$ and $d_{y z}$ rhenium orbitals and the suitable p orbitals of the $\mathrm{O}$ ligands. An ideal single Re-O bond length, predicated by the use of Pauling's oxygen covalent radius and Cotton and Lippard's value for the Re (V) octahedral covalent radius, should be around. $2.04 \AA$ [16]. Tables 3 and 4 present the atomic charge determined from the natural population analysis (NPA) for the complexes. The calculated charge on the rhenium atom is considerably lower than the formal charge of +5 (1.343).

\section{3. $[\operatorname{ReO}(\mathrm{MBT}) 2 \mathrm{OH}]$}

The most important bond lengths and angles for the compound are reported in Table 5. The gas phase structural optimization shown in Figure 3 indicates that the complex has a tetrahedral geometry. However, in the presence of a solvent, the attachment of solvent molecules to form distorted square pyramidal structures has been confirmed by measuring the absorption spectra of the complexes in different solvent and recording the change in wave length caused by a variety of solvents.

\subsection{The Analytical Data}

Table 6 summarizes some analytical data and properties of the prepared complexes. The reaction gives oxorhenium complexes in good yields. The elemental analysis provides a good agreement between the experimental data and the calculated values (Scheme 1).

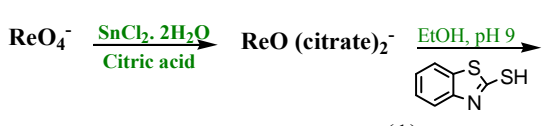

(1)

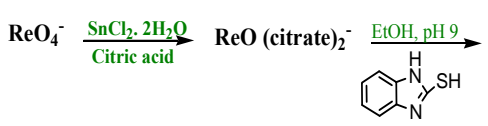

(2)

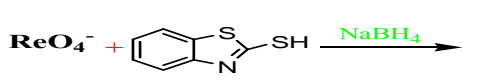

(3)
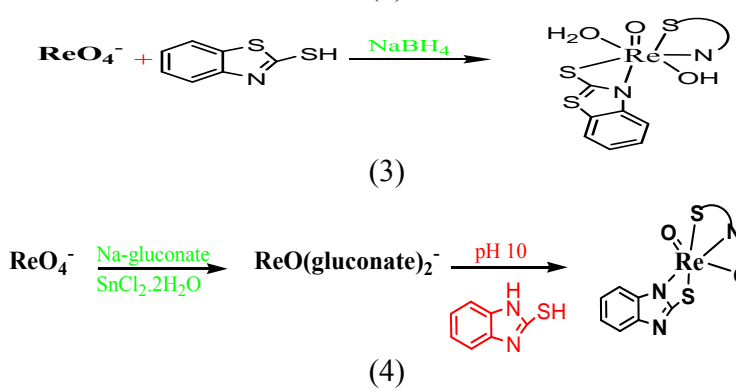

Scheme 1. Synthesis of complex.
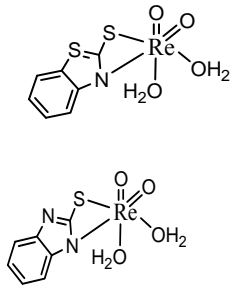


\subsection{The IR spectra}

In the IR spectrum, a weak broad band was observed with a maximum at $3445 \mathrm{~cm}^{-1}$, shown in Figure 4. This band was predicted at $3526 \mathrm{~cm}^{-1}$ in the DFT calculation of monomeric MBT thione (II) for NH stretching vibrations, as shown in Table 7. This result indicates the existence of a monomeric thione form of MBT. Our $a b$ initio calculations for MBT explain the bands at 3115 and $3069 \mathrm{~cm}^{-1}$ as symmetric and asymmetric NH stretching vibrations, and the peak observed at $3041 \mathrm{~cm}^{-1}$ can be explained as asymmetric $\mathrm{CH}$ stretching vibrations (Figure 5).

Our calculations predicted that the intense bands observed at 1244,1425 and $1495 \mathrm{~cm}^{-1}$ are associated to the vibrations of C-N-H group. The intense band observed at $1455 \mathrm{~cm}^{-1}$ is a result of attributed to CC and CN stretch-

Table 3. Atomic charges from the Natural Population analysis (NPA) for $\left[\mathrm{ReO}_{2}(\mathrm{MBT})\left(\mathrm{H}_{2} \mathrm{O}\right)_{2}\right]$

\begin{tabular}{cc}
\hline Atom & Atomic charge \\
\hline $\mathrm{Re}(15)$ & 1.3439 \\
$\mathrm{O}(16)$ & -1.0824 \\
$\mathrm{~N}(9)$ & -0.56149 \\
$\mathrm{O}(17)$ & -0.73924 \\
$\mathrm{~S}(14)$ & 0.61039 \\
$\mathrm{O}(18)$ & 0.0332 \\
$\mathrm{O}(19)$ & 0.0854 \\
\hline
\end{tabular}

Table 4. The occupancies and hybridization of the calculated natural bond orbitals (NBOs) of $\left[\mathrm{ReO}_{2}(\mathrm{MBT})\left(\mathrm{H}_{2} \mathrm{O}\right)_{2}\right]$.

\begin{tabular}{|c|c|c|}
\hline $\begin{array}{l}\mathrm{BD}(2 \text {-center } \\
\text { bond })\end{array}$ & occupancy & Hybridization of NBO \\
\hline $\mathrm{Re}(15)-\mathrm{O}(17)$ & $1.87533(0.3761)$ & $\begin{array}{c}0.6133(\mathrm{sd})_{\mathrm{Re}}+ \\
0.7899(\mathrm{p})_{\mathrm{O}}\end{array}$ \\
\hline $\operatorname{Re}(15)-\mathrm{N}(9)$ & $1.7159(0.8298)$ & $0.9109(\mathrm{sp})_{\mathrm{N}}+0.412(\mathrm{sd})_{\mathrm{Re}}$ \\
\hline
\end{tabular}

Table 5. Selected optimized bond lengths $\left(\mathrm{A}^{\circ}\right)$ and angles $\left(^{\circ}\right)$ for $\left[\mathrm{ReO}(\mathrm{MBT})_{2} \mathrm{OH}\right]$

\begin{tabular}{ccc}
\hline Bond length $\left(\mathrm{A}^{\circ}\right)$ & Bond angles $\left(^{\circ}\right)$ & B3LYP/LANL2DZ \\
\hline $\operatorname{Re}(29)-\mathrm{O}(31) 1.696$ & $\mathrm{O}(31)-\operatorname{Re}(29)-\mathrm{S}(27)$ & 113.971 \\
$\operatorname{Re}(29)-\mathrm{O}(30) 1.881$ & $\mathrm{O}(30)-\operatorname{Re}(29)-\mathrm{S}(28)$ & 100.2773 \\
$\operatorname{Re}(29)-\mathrm{S}(27) 2.355$ & $\operatorname{Re}(29)-\mathrm{O}(30)-\mathrm{H}(32)$ & 131.865 \\
$\operatorname{Re}(29)-\mathrm{S}(28) 2.336$ & $\mathrm{~S}(27)-\operatorname{Re}(29)-\mathrm{S}(30)$ & 110.951 \\
\hline
\end{tabular}

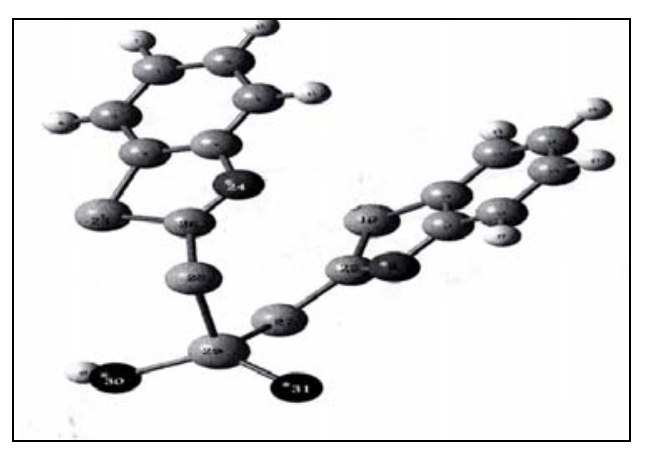

Figure 3. Optimized structure of $\left[\mathrm{ReO}(\mathrm{MBT})_{2} \mathrm{OH}\right]$.

Table 6. The analytical data of complexes.

\begin{tabular}{|c|c|c|c|c|c|c|c|}
\hline \multirow{2}{*}{$\begin{array}{l}\text { Complex/ } \\
\text { Theoretical Formula }\end{array}$} & \multirow[t]{2}{*}{ Color } & \multirow{2}{*}{$\begin{array}{c}\text { Yield } \\
\%\end{array}$} & \multirow{2}{*}{$\begin{array}{c}\text { Decomposition } \\
\text { Temp } \\
{ }^{\circ} \mathrm{C}>\end{array}$} & \multicolumn{4}{|c|}{$\begin{array}{c}\text { Elemental Analysis \% } \\
\text { Calc.(Found) }\end{array}$} \\
\hline & & & & $\mathrm{C}$ & $\mathrm{H}$ & $\mathrm{N}$ & $\mathrm{Re}$ \\
\hline $\begin{array}{c}{\left[\mathrm{ReO}_{2}(\mathrm{MBT})\left(\mathrm{H}_{2} \mathrm{O}\right)_{2}\right] \mathbf{I}} \\
\mathrm{C}_{7} \mathrm{H}_{8} \mathrm{~S}_{2} \mathrm{NO}_{4} \mathrm{Re} \\
\end{array}$ & $\begin{array}{l}\text { Dark- } \\
\text { green }\end{array}$ & 89 & 300 & $\begin{array}{c}20.0 \\
(20.02) \\
\end{array}$ & $\begin{array}{c}1.9 \\
(1.78)\end{array}$ & $\begin{array}{c}3.33 \\
(3.20) \\
\end{array}$ & $\begin{array}{c}44.3 \\
(42.2) \\
\end{array}$ \\
\hline $\begin{array}{c}{\left[\mathrm{ReO}_{2}(\mathrm{BImz})\left(\mathrm{H}_{2} \mathrm{O}\right)_{2}\right] \mathbf{I I}} \\
\mathrm{C}_{7} \mathrm{H}_{8} \mathrm{SN}_{2} \mathrm{O}_{4} \mathrm{Re}\end{array}$ & Yellow & 89.7 & 300 & $\begin{array}{c}20.8 \\
(20.52) \\
\end{array}$ & $\begin{array}{c}1.99 \\
(1.95)\end{array}$ & $\begin{array}{c}6.90 \\
(6.24) \\
\end{array}$ & $\begin{array}{l}46.30 \\
(44.7) \\
\end{array}$ \\
\hline $\begin{array}{c}{\left[\mathrm{ReO}(\mathrm{Bimz})_{2} \mathrm{OH}\right] \mathrm{III}} \\
\mathrm{C}_{14} \mathrm{H}_{9} \mathrm{~N}_{4} \mathrm{O}_{2} \mathrm{~S}_{2} \mathrm{Re}\end{array}$ & Gray & 98 & 300 & $\begin{array}{c}32.60 \\
(32.33)\end{array}$ & $\begin{array}{c}1.74 \\
(1.85)\end{array}$ & $\begin{array}{c}10.86 \\
(10.78)\end{array}$ & \\
\hline $\begin{array}{c}{\left[\mathrm{ReO}(\mathrm{MBT})_{2} \mathrm{OH}\right] \mathbf{I V}} \\
\mathrm{C}_{14} \mathrm{H}_{12} \mathrm{~S}_{4} \mathrm{~N}_{2} \mathrm{O}_{2} \mathrm{Re} \\
\end{array}$ & Green & 86 & 300 & $\begin{array}{c}29.3 \\
(29.12) \\
\end{array}$ & $\begin{array}{c}2.09 \\
(2.28) \\
\end{array}$ & $\begin{array}{c}4.91 \\
(4.82) \\
\end{array}$ & $\begin{array}{c}32.6 \\
(30.99) \\
\end{array}$ \\
\hline
\end{tabular}

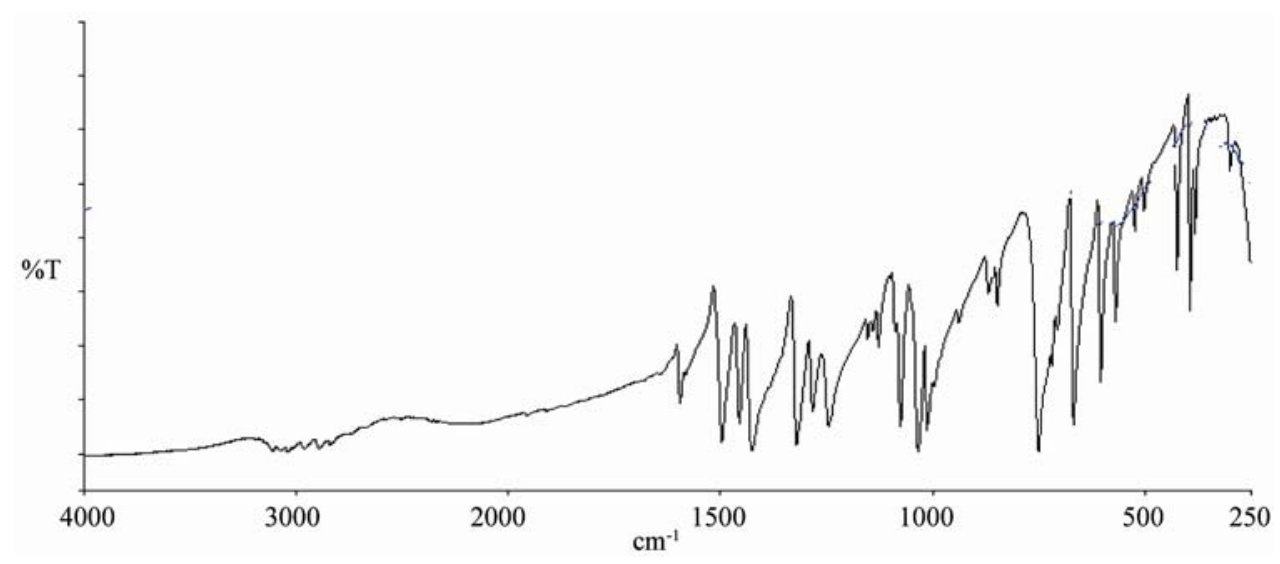

Figure 4. IR spectra of (MBT) ligands . 


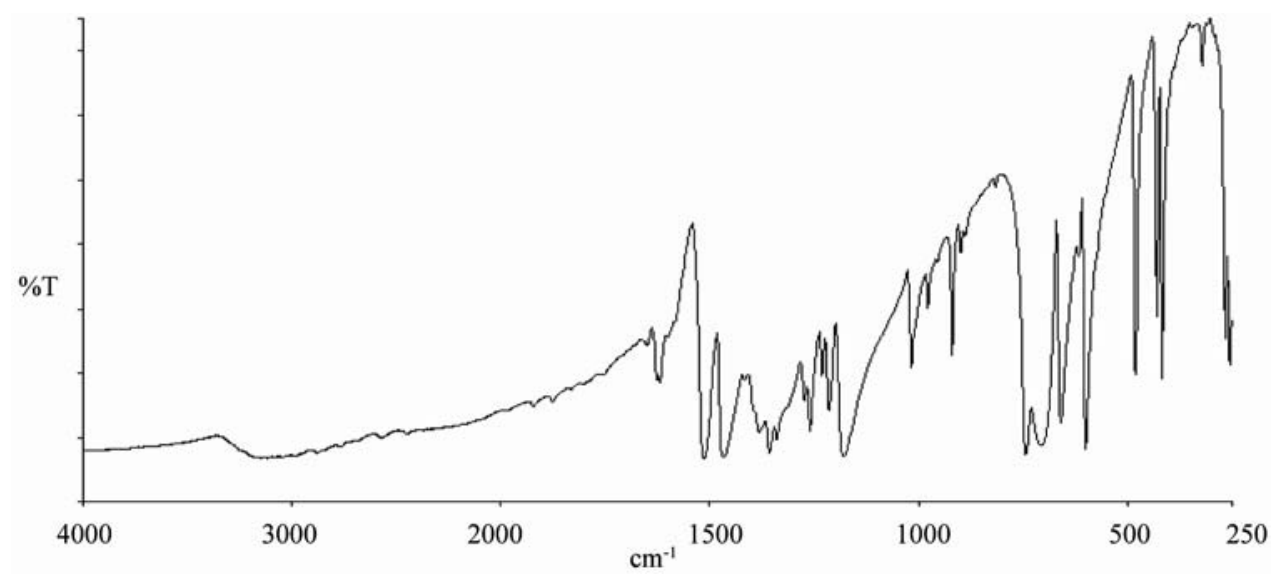

Figure 5. IR spectra of (Bimz) ligands

ing and $\mathrm{CH}$ bending vibrations. The strong bands at 1012,1033 and $1076 \mathrm{~cm}^{-1}$ are predicted to $\mathrm{N}-\mathrm{C}=\mathrm{S}$ group in addition to $\mathrm{CCC}$ and $\mathrm{CH}$ bending vibrations [18, 19]. The very weak bands observed at 2640 and 2480 $\mathrm{cm}^{-1}$ can be interpreted as overtone bands of the fundamental frequencies at 1319 and $1244 \mathrm{~cm}^{-1}$. The band observed at $-1595 \mathrm{~cm}^{-1}$ is ascribed to a $\mathrm{C}=\mathrm{C}$ stretching mode. The intense band observed at $1455 \mathrm{~cm}^{-1}$ is attributed to $\mathrm{CC}, \mathrm{CN}$ stretching and $\mathrm{CH}$ bending vibrations. The strong bands at 1012, 1033 and $1076 \mathrm{~cm}^{-1}$ represent the $\mathrm{N}-\mathrm{C}=\mathrm{S}$ group in addition to $\mathrm{CCC}$ and $\mathrm{CH}$ bending vibrations. The symmetric out-of-plane $\mathrm{CH}$ vibration was observed as a very strong band at $750 \mathrm{~cm}^{-1}$. The strong band observed at $668 \mathrm{~cm}^{-1}$ and the weak bands at 603 and $706 \mathrm{~cm}^{-1}$ were attributed to C-S stretching modes [19]. It should be mentioned that the theoretical values are usually higher than the experimental data. It is necessary to scale the theoretical data by an optimal scaling factor (0.996) that varies with the basis set [20].

From Figure 6 (C) IR spectra of complex $\left[\mathrm{ReO}_{2}\right.$ (MBT) $\left(\mathrm{H}_{2} \mathrm{O}\right)_{2}$ ] showed two characteristic peaks, at 914 and $860 \mathrm{~cm}^{-1}$, and $\left[\mathrm{ReO}_{2}(\mathrm{Bimz})\left(\mathrm{H}_{2} \mathrm{O}\right)_{2}\right]$ assigned at 908 , $843 \mathrm{~cm}^{-1}$. These values are typical of cis-dioxo $\mathrm{O}=\mathrm{Re}=\mathrm{O}$ group of the cis-dioxorhenium(V) coordinated complexes $[17,21]$. In Figure 6. (B) show that $v \mathrm{Re}=\mathrm{O}$ has been detected on $912 \mathrm{~cm}^{-1}$ for complex [ReO(MBT) $)_{2} \mathrm{OH}$, and $v$ Re-O and $v$ Re-S at 649 and $432 \mathrm{~cm}^{-1}$, respectively as compare with free ligand (A) MBT. In Figure 7 (C) as shown that $v \mathrm{Re}=\mathrm{O}$ has been detected on $908 \mathrm{~cm}^{-1}$ and absences of the medium band for vNH at $3117 \mathrm{~cm}^{-1}$ and the coordinated bonded at $v \operatorname{Re}-\mathrm{N}, v \operatorname{Re}-\mathrm{O}$ and $v \mathrm{Re}-\mathrm{S}$ at 546,415 and $619 \mathrm{~cm}^{-1}$, respectively. The infrared spectra of the rest complexes show bands in the region3304 $3458 \mathrm{~cm}^{-1}$ corresponding to $v \mathrm{OH}$ stretching and the bands at $1650-1580 \mathrm{~cm}^{-1}$ vibration due to $\mathrm{HOH}$ bending. Some bands are disappearing in some complexes such as $\mathrm{SH}$ and $\mathrm{NH}$ at -2889 and $-3117 \mathrm{~cm}^{-1}$ respectively, these indicating that these donor atoms were de- protonated upon complexation.

\subsection{The NMR spectra}

The ${ }^{1} \mathrm{H}$ NMR spectra of a series of mercapto complexes show signals assigned to the Ha,b,c,d (the protons of the benzene ring) in different chemical shifts caused by the anisotropic effect, which laminated the protons oriented toward the oxygen that appear deshielded relative to the other protons oriented away from the oxygen ( toward or away from the oxo-metal core) [18] (Figure 8).

As we see the protons near the $\mathrm{Re}=\mathrm{O}$ core was assigned to the downfield region of the spectrum at -7.7 $7.6 \mathrm{ppm}[16-20]$. The Bimz-complexes demonstrate the same chemical shift behavior as the MBT-complexes. The ${ }^{13} \mathrm{C}$ NMR spectra of the complexes exhibit two new characteristic peaks for $\mathrm{C}=\mathrm{S}$ and $\mathrm{C}-\mathrm{N}$ at lower fields of 189 and 141 ppm compared with the spectra of free ligand MBT, indicating that coordination via the charged thiolic sulfur and nitrogen atoms occurred (Figures 9-11). All of the NMR spectra

Table 7. The vibrational assignment, experimental and calculated wave numbers in $\mathrm{cm}^{-1}$ of MBT and Bimz.

\begin{tabular}{ccc}
\hline Experimental & B3LYP/LANL2DZ & Assignment \\
\hline MBT & 3526 & $\mathrm{NH}$ \\
3445 & 3526 & Asymmetric NH str. \\
$3115(\mathrm{vw})$ & 3187 & Asymmetric CH str. \\
3041,2889 & 1671 & $\mathrm{C}=\mathrm{C}$ str. \\
1595 & 1508 & $\mathrm{C}-\mathrm{C}$ str.,$(\mathrm{C}-\mathrm{N}-\mathrm{H})$ \\
$1497,1425,1244$ & 1234,1342 & (N-C=S), C=S \\
$1012,1033,1076$ & 963 & Out.o.p. asym \\
750,668 & 885 & $\mathrm{C}-\mathrm{S}$ \\
706,603 & 438 & $\mathrm{~S}-\mathrm{C}=\mathrm{S}$ bend. \\
394 & 3684 & \\
Bimz & 3210 & $\mathrm{NH}$ \\
3455 & 2990 & Asymmetric NH str. \\
$3117(\mathrm{vw})$ & 1671 & Asymmetric CH str. \\
2880 & 1506 & $\mathrm{C}=\mathrm{C}$ str. \\
1618 & 1199 & $\mathrm{C}-\mathrm{C}$ str.,$(\mathrm{C}-\mathrm{N}-\mathrm{H})$ \\
1466,1356 & 962 & (N-C=S), C=S \\
1178 & 1633 & Out.o.p. asym \\
743,659 & & $\mathrm{C}=\mathrm{N}$ \\
1513 & &
\end{tabular}




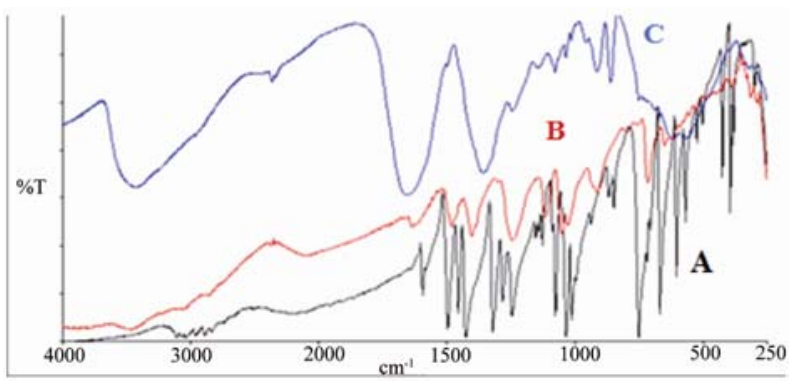

Figure 6. IR spectrum of A: MBT B: $\left[\mathrm{ReO}(\mathrm{MBT})_{2} \mathrm{OH}\right] \mathrm{C}$ : $\left[\mathrm{ReO}_{2}(\mathrm{MBT})\left(\mathrm{H}_{2} \mathrm{O}\right)_{2}\right]$.

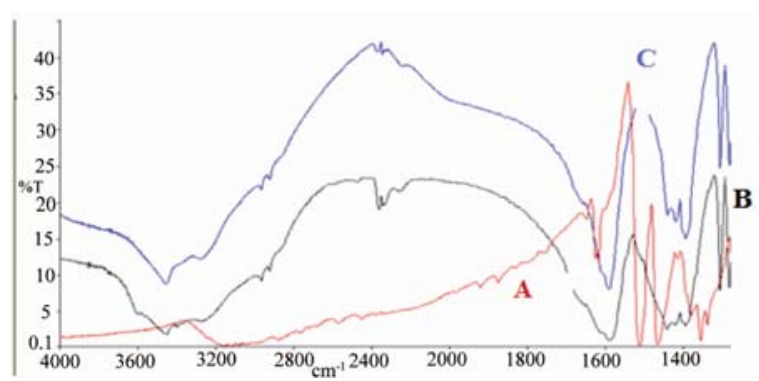

Figure 7. IR spectrum of A:Bimz B: $\left[\mathrm{ReO}_{2}(\mathrm{Bimz})\left(\mathrm{H}_{2} \mathrm{O}\right)_{2}\right] \mathrm{C}$ : $\left[\mathrm{ReO}(\mathrm{Bimz})_{2} \mathrm{OH}\right]$.

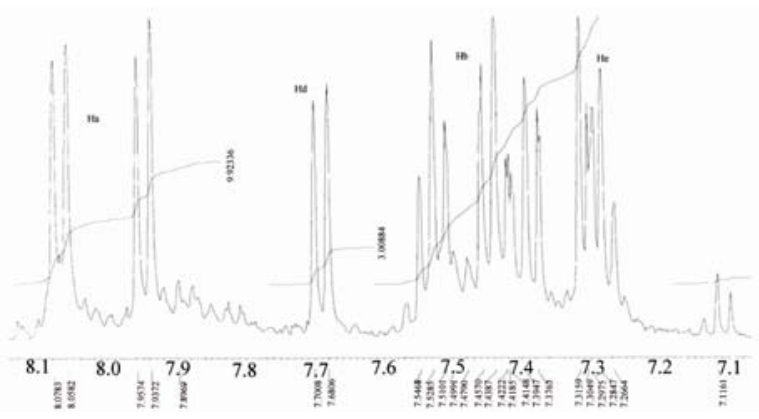

Figure 8. ${ }^{1} \mathrm{H}$ NMR of benzene ring of mercapto-complexes.

of the complexes are listed in Table 8 .

\subsection{Electronic Spectrum}

Table 9 show typical UV-Vis spectra with two signifycant absorption bands, one of them in the UV region at about $205-240 \mathrm{~nm}$ corresponding to the $\boldsymbol{\pi} \rightarrow \boldsymbol{\pi} *$ band, and the other in the visible region at approximately 350 $\mathrm{nm}$, which is characteristic of metal-oxygen complexes. [19-22]. The UV-Vis spectrum of [ReO(MBT) $\left.)_{2} \mathrm{OH}\right]$ IV exhibits a few intense absorption bands in the range of $400-200 \mathrm{~nm}$. The absorption band at $359 \mathrm{~nm}$ is assigned to the electronic transitions calculated in the range of 390 - $309 \mathrm{~nm}$. They have LMCT (Ligand-Metal Charge Transfer) character and originate from the oxo, MBT and $\mathrm{OH}$ ligands to the d-Rhenium orbitals. The experimental bands below $300 \mathrm{~nm}$ result mainly from Ligand-Metal Charge Transfer. $\pi(\mathrm{O}) \rightarrow d$, Ligand-Ligand

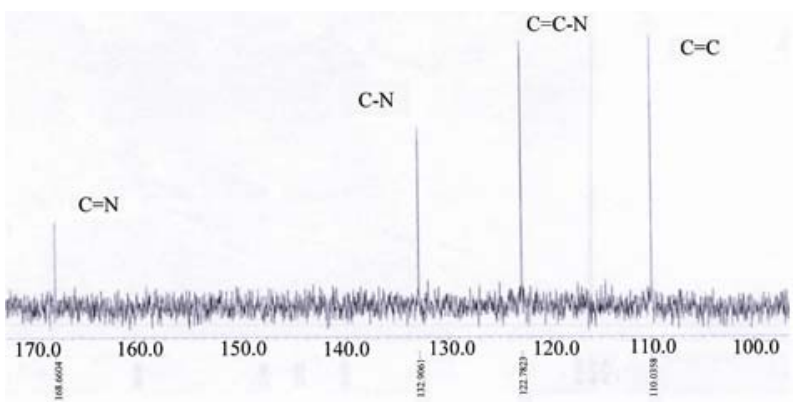

Figure $9 .{ }^{13} \mathrm{CNMR}$ of $\left[\mathrm{ReO}(\mathrm{MBT})_{2} \mathrm{OH}\right]$ IV complex.

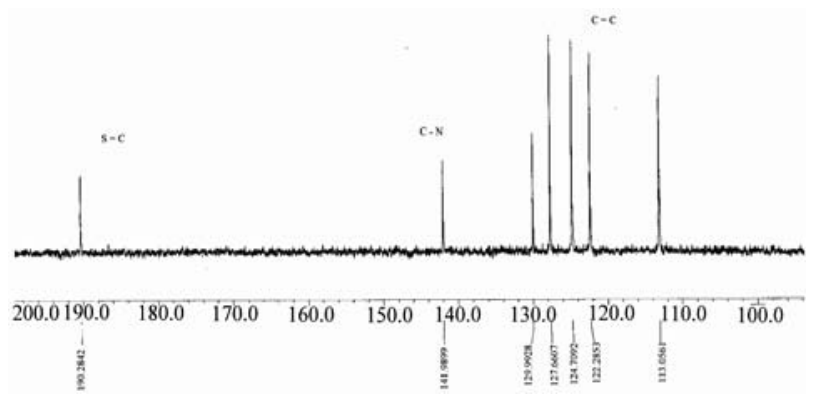

Figure 10. ${ }^{13} \mathrm{C}$ NMR of $\left[\mathrm{ReO}_{2}(\mathrm{MBT})\left(\mathrm{H}_{2} \mathrm{O}\right)_{2}\right]$ I complex.

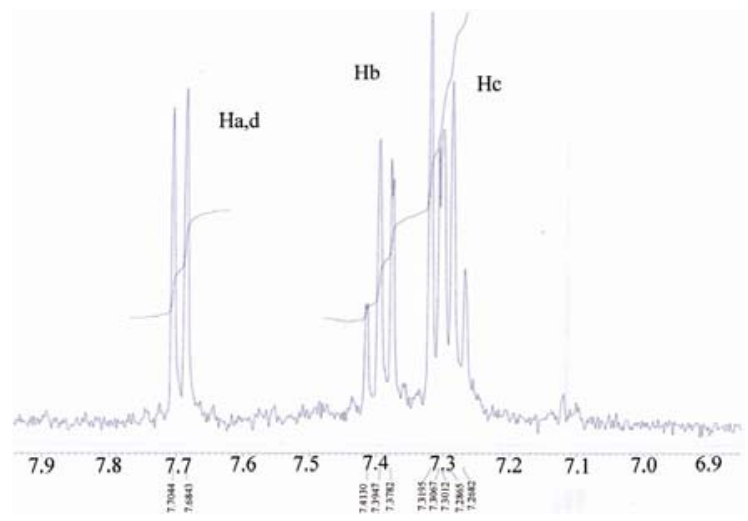

Figure 11. ${ }^{1} \mathrm{H}$ NMR of $\left[\mathrm{ReO}_{2}(\mathrm{MBT})\left(\mathrm{H}_{2} \mathrm{O}\right)_{2}\right]$ I complex.

Charge Transfer: $n \rightarrow \pi^{*}$ transitions and intraligand (IL) transitions: $\pi \rightarrow \pi^{*}$ [18]. (Figures 12-15).

\subsection{Mass Spectroscopy}

The mass spectra of the investigated complexes show two major peaks with $\mathrm{m} / \mathrm{z}$ at 553 and 429 attributed to anionic species of $\left[\mathrm{ReO}(\mathrm{MBT})_{2} \mathrm{OH}\right],\left[\mathrm{ReO}_{2}(\mathrm{MBT})\right]$, respectively. For complex $\left[\mathrm{ReO}_{2}(\mathrm{MBT})\right]$ three fragments at $180 \mathrm{~m} / \mathrm{z}, 167 \mathrm{~m} / \mathrm{z}$ and $68 \mathrm{~m} / \mathrm{z}$, were ascribed to $[\mathrm{ReO}]^{3+}$, (MBT) and benzene fragmentation species, respectively. All the results of MS spectra support with other spectroscopic data investigated in this work for dedication of chemical structure of the investigated complexes. However, fragments observed confirmed validity of the structures as shown in Table $\mathbf{1 0 .}$ 
Table 8.The NMR data for ligand and complexes. $(\delta, \mathrm{ppm})^{\mathrm{a}}$,

\begin{tabular}{|c|c|c|}
\hline Compounds & ${ }^{1} \mathrm{H}$ NMR $(\delta$, ppm $) ;$ Assignment & ${ }^{13} \mathrm{C}$ NMR $(\delta$, ppm $) ;$ Assignment \\
\hline MBT & $3(\mathrm{~s}, \mathrm{SH}), 8.1(\mathrm{~d}, 1 \mathrm{H}), 7.55(\mathrm{~m}, 2 \mathrm{H}), 8.23(\mathrm{~s}, 1 \mathrm{H})$ & $\begin{array}{c}122,123,126,127(\mathrm{C}=\mathrm{C}), 133(\mathrm{C}=\mathrm{C}-\mathrm{C}-\mathrm{S}), 153(\mathrm{C}-\mathrm{N}), 156 \\
(\mathrm{~N}=\mathrm{C})\end{array}$ \\
\hline$\underset{\text { I }}{\left[\mathrm{ReO}_{2}(\mathrm{MBT})\left(\mathrm{H}_{2} \mathrm{O}\right)_{2}\right]}$ & $7.7(\mathrm{~m}, 2 \mathrm{H}), 7.4(\mathrm{~m}, 1 \mathrm{H}), 7.2(\mathrm{~m}, 1 \mathrm{H})$ ring & $\begin{array}{c}122,123,126,127(\mathrm{C}=\mathrm{C}), 133(\mathrm{C}=\mathrm{C}-\mathrm{C}-\mathrm{S}) \\
189(\mathrm{~S}=\mathrm{C}), 141(\mathrm{C}=\mathrm{C}-\mathrm{C}-\mathrm{N})\end{array}$ \\
\hline Bimz & $\begin{array}{c}3(\mathrm{~s}, \mathrm{SH}), 5(\mathrm{~s}, \mathrm{NH}), 7.7(\mathrm{~d}, 1 \mathrm{H}), 7.26(\mathrm{~m}, 2 \mathrm{H}) \\
7.7(\mathrm{~s}, 1 \mathrm{H}) \text { ring }\end{array}$ & $122,123,115,115(\mathrm{C}=\mathrm{C}), 137(\mathrm{C}-\underline{\mathrm{C}}-\mathrm{N}), 141(\mathrm{~N}=\underline{\mathrm{C}}-\mathrm{S})$ \\
\hline$\underset{\text { II }}{\left[\mathrm{ReO}_{2}(\mathrm{Bimz})\left(\mathrm{H}_{2} \mathrm{O}\right)_{2}\right]}$ & $7.1(\mathrm{~m}, 2 \mathrm{H}), 7.5(\mathrm{~m}, 1 \mathrm{H}), 7.6(\mathrm{~s}, 1 \mathrm{H})$ ring & $110(C=C), 122(C=C-N), 132(C-N), 168(C=N)$. \\
\hline$\left[\mathrm{ReO}(\mathrm{Bimz})_{2} \mathrm{OH}\right] \mathbf{I I I}$ & 7.1(m, 1H), 7.1(m, 1H ), 7.3(m,1H), 7.6(m,1H) & $112(\mathrm{C}=\mathrm{C}), 121(\mathrm{C}=\mathrm{C}-\mathrm{N}), 179(\mathrm{C}=\mathrm{N}) \cdot 45\left(\mathrm{CH}_{2}\right)$ \\
\hline$\left[\mathrm{ReO}(\mathrm{MBT})_{2} \mathrm{OH}\right] \mathbf{I V}$ & 7.7 (m,2H), 7.4(m,H1), 7.2(m,1H) ring, & $122,124,127,129,113(\mathrm{C}=\mathrm{C}-\mathrm{S}), 141(\mathrm{C}=\mathrm{C}-\underline{\mathrm{C}}-\mathrm{N}), 190(\mathrm{~S}=\mathrm{C})$. \\
\hline
\end{tabular}

Table 9.The Electronic data of free ligands and complexes.

\begin{tabular}{ccc}
\hline Compound & $\begin{array}{c}\lambda_{\max }[\mathrm{nm}] \\
\left(\varepsilon ; \mathrm{dm}^{3} \mathrm{~mol}^{-1} \mathrm{~cm}^{-1}\right)\end{array}$ & Assignment \\
\hline MBT & $212(519), 247(767)$ & $\pi \rightarrow \pi^{*}, \mathrm{n} \rightarrow \pi^{*}$ \\
{$\left[\mathrm{ReO}_{2}(\mathrm{MBT})\left(\mathrm{H}_{2} \mathrm{O}\right)_{2}\right] \mathbf{I}$} & $205(1582), 219(1044), 355(1499)$ & $\pi \rightarrow \pi^{*}, \pi \rightarrow \pi^{*}, \pi(\mathrm{O}) \rightarrow d$ \\
Bimz & $224(3080), 244(3429), 298(3161)$ & $\pi \rightarrow \pi^{*}, \pi \rightarrow \pi^{*}, \mathrm{n} \rightarrow \pi^{*}$ \\
{$\left[\mathrm{ReO}_{2}(\mathrm{Bimz})\left(\mathrm{H}_{2} \mathrm{O}\right)_{2}\right] \mathbf{I I}$} & $190(1911), 245 \mathrm{~nm}(456), 300(315)$ & $\pi \rightarrow \pi^{*}, \mathrm{n} \rightarrow \pi^{*}, \pi(\mathrm{O}) \rightarrow d$ \\
{$\left[\mathrm{ReO}(\mathrm{Bimz})_{2} \mathrm{OH}\right] \mathbf{I I I}$} & $240(3000), 325(2060)$ & $\pi \rightarrow \pi^{*}, \pi(\mathrm{O}) \rightarrow d$ \\
{$\left[\mathrm{ReO}(\mathrm{MBT})_{2} \mathrm{OH}\right] \mathbf{I V}$} & $209(1556), 233(1055), 359(1498)$ & $\pi \rightarrow \pi^{*}, \pi \rightarrow \pi^{*}, \pi(\mathrm{O}) \rightarrow d$ \\
\hline
\end{tabular}

Table 10.Mass spectra data of Re-complexes.

\begin{tabular}{|c|c|c|}
\hline Complexes & $\approx \mathrm{Mwt}$ & Most relative intensity $(\mathrm{m} / \mathrm{z})$ \\
\hline$\left[\mathrm{ReO}_{2}(\mathrm{MBT})\left(\mathrm{H}_{2} \mathrm{O}\right)_{2}\right] \mathbf{I}$ & 420 & $\mathrm{ReO}_{2}(218), \mathrm{ReO}_{2}(\mathrm{MBT})(385), \mathrm{MBT}(167)$, Benzothazole (135), Bz(95,78, 61,44). \\
\hline$\left[\mathrm{ReO}_{2}(\mathrm{Bimz})\left(\mathrm{H}_{2} \mathrm{O}\right)_{2}\right] \mathbf{I I}$ & 402 & $\mathrm{ReO}_{2}(\mathrm{BImz})(355), \mathrm{Re}(\mathrm{BImz})(336), \mathrm{BImz}(148), \mathrm{Bz}(95,78,61,44)$. \\
\hline$\left[\mathrm{ReO}(\mathrm{MBT})_{2} \mathrm{OH}\right] \mathbf{I V}$ & 570 & $\begin{array}{l}\mathrm{ReO}(\mathrm{MBT})_{2}(553), 2 \mathrm{MBT}(268), \mathrm{MBT}(167), \text { Methyl-MBT(181), Benzotha- } \\
\text { zole(135),Bz( }(95,78,61,44) .\end{array}$ \\
\hline
\end{tabular}

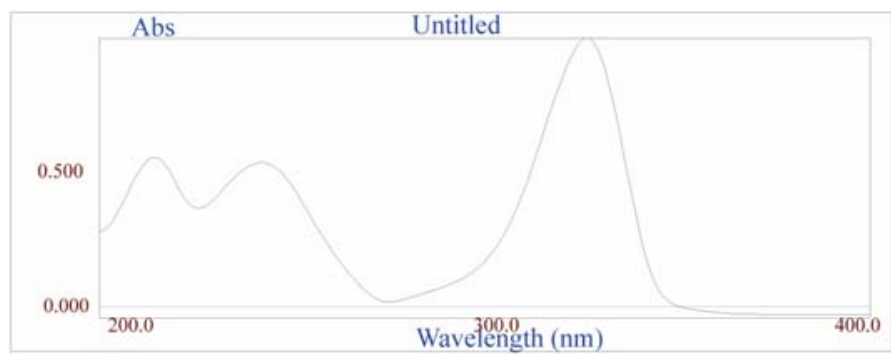

Figure 12. UV spectra of $\left[\mathrm{ReO}(\mathrm{MBT})_{2} \mathrm{OH}\right]$ complex.

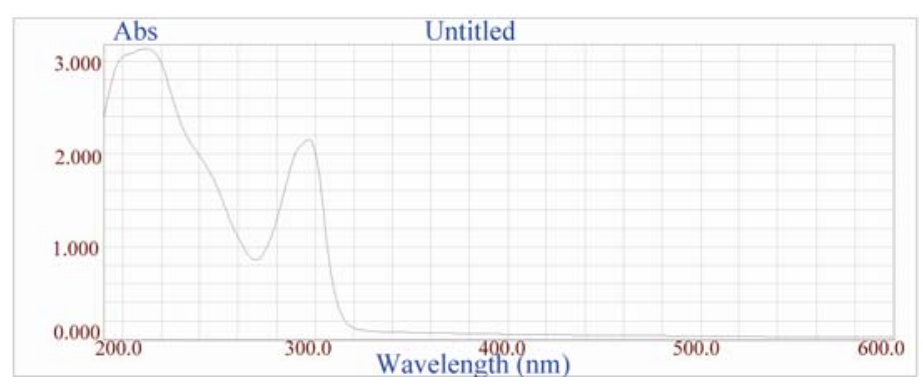

Figure 13. UV spectra of $\left[\mathrm{ReO}(\mathrm{Bimz})_{2} \mathrm{OH}\right]$ complex.

\subsection{Thermal analysis of complexes}

As noted in Table 11 there is a good agreement between the calculated percentages of decomposition steps based on the proposed structures and the experimentally deter- mined data. These results provide further evidence for the plausibility investigated structures. The black residue can be attributed to metal oxides $\left(\mathrm{Re}_{2} \mathrm{O}_{3}, 27.4 \%\right)$ (Figure 16). 


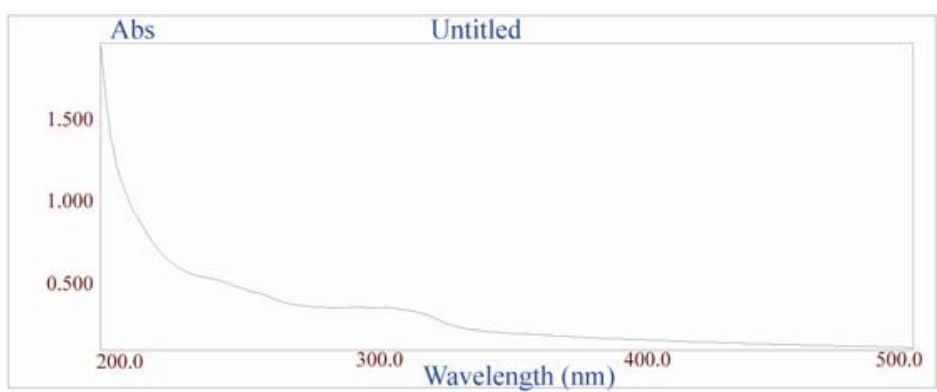

Figure 14. UV spectra of $\left[\mathrm{ReO}_{2}(\mathrm{Bimz})\left(\mathrm{H}_{2} \mathrm{O}\right)_{2}\right]$ complex.

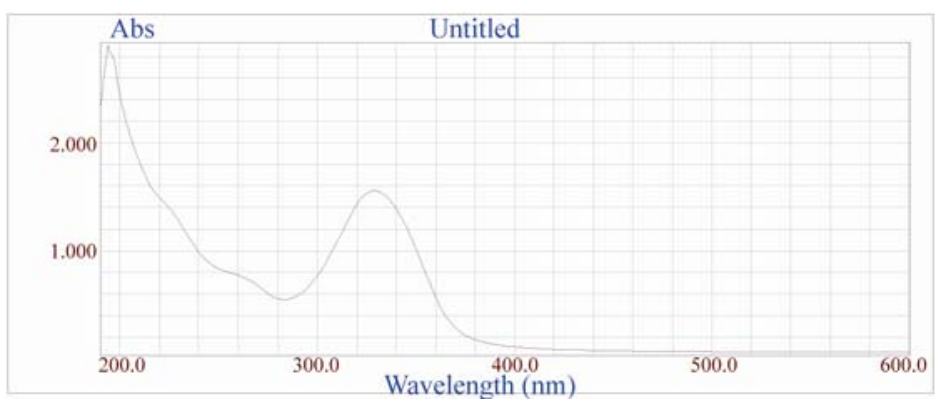

Figure 15. UV spectra of $\left[\mathrm{ReO}_{2}(\mathrm{MBT})\left(\mathrm{H}_{2} \mathrm{O}\right)_{2}\right]$ complex.

Table 11. The TG data of complexes.

\begin{tabular}{|c|c|c|c|c|}
\hline Complex & \multicolumn{2}{|c|}{$\begin{array}{c}\text { Decomposition step } \\
\text { Anal(Calc) } \%\end{array}$} & $\begin{array}{c}\text { Temp } \\
{ }^{\circ} \mathrm{C}\end{array}$ & Assignment \\
\hline \multirow{2}{*}[\mathrm{ReO}_{2}(\mathrm{MBT})(\mathrm{H}_{2}\mathrm{O})_{2}]{$\mathbf{I}$} & First step & $7.5(8.5)$ & $50-150$ & Loss of $2 \mathrm{H}_{2} \mathrm{O}$ \\
\hline & Second step & $37(39.5)$ & $200-600$ & Loss of MBT \\
\hline \multirow{2}{*}[\mathrm{ReO}_{2}(\mathrm{Bimz})(\mathrm{H}_{2}\mathrm{O})_{2}]{$\mathbf{I I}$} & First. step & $7.6(8.9)$ & $100-250$ & Loss of $2 \mathrm{H}_{2} \mathrm{O}$ \\
\hline & Second. step & $25.8(29)$ & $250-600$ & Loss of Bimz \\
\hline \multirow{2}{*}[\mathrm{ReO}(\mathrm{MBT})_{2}\mathrm{OH}]{$\mathbf{I V}$} & First. step & $4.99(6.11)$ & $50-190$ & Loss of $\mathrm{OH}$ \\
\hline & Second. step & $58(54)$ & $200-600$ & Loss of $2 \mathrm{MBT}$ \\
\hline
\end{tabular}

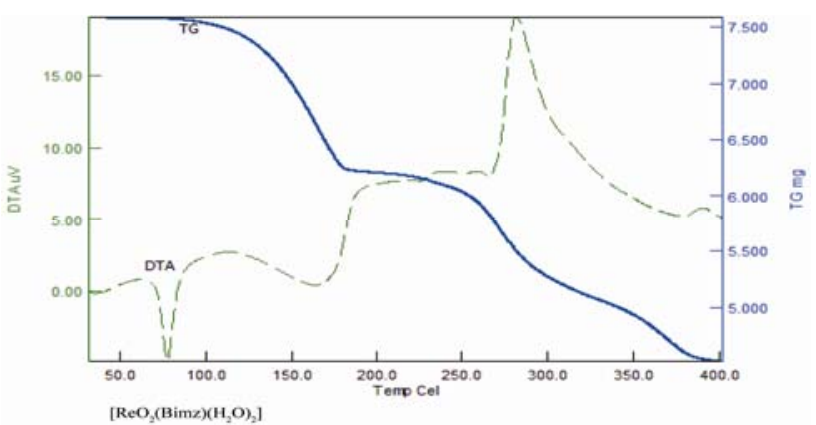

(a)

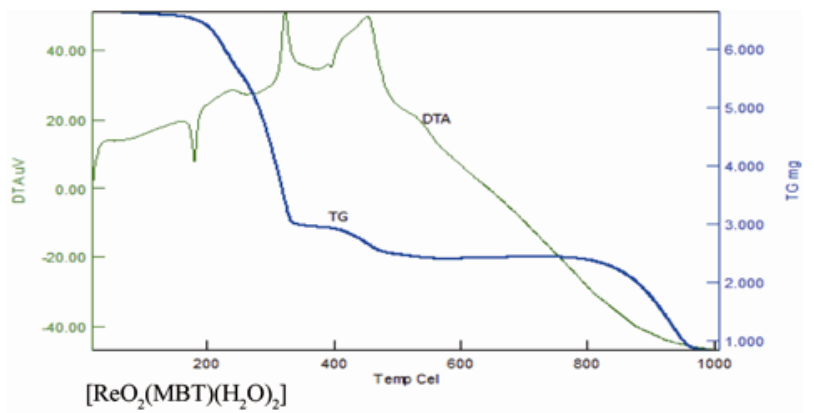

(b) 


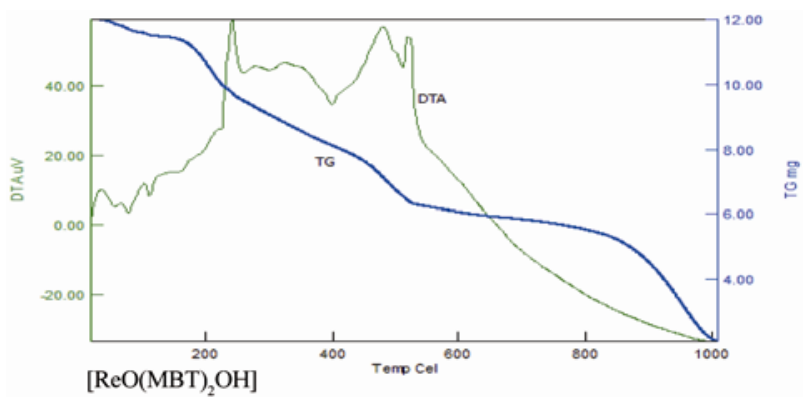

(c)

Figure 16. TG and DTA of complexes.

\section{CONCLUSIONS}

The experiments showed that suitable complexation of monodentate and bi-dentate $\mathrm{S} / \mathrm{N}$ and mono-dentate $\mathrm{S} / \mathrm{N}$ ligands was able to stabilize the $\left[\mathrm{Re}^{\mathrm{V}}=\mathrm{O}\right]$ core. In this paper, we reported the synthesis of a series of novel oxorhenium (V) complexes, $\left[\mathrm{ReO}_{2}(\mathrm{MBT})\left(\mathrm{H}_{2} \mathrm{O}\right)_{2}\right]$ I, $\left[\mathrm{ReO}_{2}(\mathrm{Bimz})\left(\mathrm{H}_{2} \mathrm{O}\right)_{2}\right]$ II, [ $\left.\mathrm{ReO}(\mathrm{Bimz})_{2} \mathrm{OH}\right]$ III, and [ $\mathrm{ReO}$ $\left.(\mathrm{MBT})_{2} \mathrm{OH}\right]$ IV. The compounds were fully characterized by means of spectroscopy methods. Density functional calculations for the $\left[\mathrm{ReO}_{2}(\mathrm{MBT})\left(\mathrm{H}_{2} \mathrm{O}\right)_{2}\right]$ I and $\left[\mathrm{ReO}(\mathrm{MBT})_{2} \mathrm{OH}\right] \mathbf{I V}$ complexes were carried out using the DFT method with the B3LYP functional and LANL2DZ basis set. The experimentally characterized molecular structures of theses complexes have been properly reproduced by the B3LYP method.

\section{ACKNOWLEDGEMENTS}

The Authors extend their appreciation to the Deanship of Scientific Research at King Saud University for funding the work through the research group project NO. (RGP-VPP-041).

\section{REFERENCES}

[1] Chattopadhyay, P., Chiu, Y.H., Lo, J.M., Chung, C.S. and Lu, T.H. (2000). Synthesis and structural characterization of a $\operatorname{Re}(\mathrm{V})$ complex with $2 \mathrm{~N} 1 \mathrm{~S}$ donor and radiochemical behavior of its Tcanalog. Applied Radiation and Isotopes, 52, 217-223. doi:10.1016/S0969-8043(99)00156-6

[2] Papagiannopoulou. D., Pirmettis .I.C., Pelecanou. M., Tsoukalas. Ch,. Raptopoulou. C.P., Terzis. A., Chiotellis. E and Papadopoulos. M. (2001) Synthesis and structural characterization of a novel $\mathrm{Re}[\mathrm{P}][\mathrm{NN}][\mathrm{S}][\mathrm{SO}]$ mixed ligand rhenium (III) complex. Inorganica Chimica Acta, 320, 174-177.

[3] Li . X-H., Tang. Z-X. and Zhang. X-Z. (2009) Molecular structure, IR spectra of 2-mercaptobenzothiazole and 2-mercaptobenzoxazole by density functional theory and ab initio Hartree-Fock calculations. Spectrochimica Acta Part A: Molecular and Biomolecular Spectroscopy, 74, 168-173. doi:10.1016/j.saa.2009.05.026

[4] Zhang H., Dai. M., Qi.C., Li. B. and Guo. X. (2004) Synthesis, biodistribution and quantitative structure-acti- vity relationship studies of new $99 \mathrm{mTc}$ labeled pseudopeptide complexes. Applied Radiation and Isotopes, 60 643-651. doi:10.1016/j.apradiso.2003.08.010

[5] Dhara. B., Chattopadhyay. P. (2005) New oxorhenium(V) complexes with $2 \mathrm{~N} 2 \mathrm{~S}$ donor sets and radiochemical behavior of their technetium analogs. Applied Radiation and Isotopes, 62, 729-735. doi:10.1016/j.apradiso.2004.10.002

[6] Bouziotis, P., Pirmettis, I., Pelecanou, M., Raptopoulou, C.P., Terzis. A., Papadopoulos, M. and Chiotellis, E. (2001) Novel Oxorhenium and Oxotechnetium Complexes from an Aminothiol[NS]/Thiol[S] Mixed-Ligand System. Chemistry-A European Journal, 7, 3671-3680. doi:10.1002/1521-3765(20010903)7:17<3671::AID-CHE M3671>3.0.CO;2-L

[7] Gaussian 98 program, Gaussian, Inc. Pittsburgh. PPA 15106 USA.

[8] Becke A.D and Pérez-Jordá. J. (1995) A density-functional study of van der Waals forces: rare gas diatomics. Chemical Physics Letters, 233, 134-137. doi:10.1016/0009-2614(94)01402-H

[9] Parr, R.G. and Liu .S. (2000) Homogeneities in density of various LDA energy functional. Journal of Molecular Structure: Theochem, 501-502, 29-34. doi:10.1016/S0166-1280(99)00410-8

[10] Hay, P.J., Chen, S.P., Voter. A.F,.Albers, R.C., Boring, A.M. (1989) Theoretical studies of grain boundaries in Ni3Al with boron or sulfur. Scripta Metall, 23, 217-222.

[11] Glendening, E.D, Reed., A.E, Carpenter, .J.E and Weinhold, F, NBO (version 3.1).

[12] Casida. M.E, (1996) Recent Development and Applications in Modern Density Functional Theory. In: Seminario, J.M. Ed., 4, Elsevier, Amsterdam.

[13] Machura ,B., Kruszynski, R. and Kusz, J. (2008) Novel oxorhenium complexes with 2-(20-hydroxyphenyl)-2benzothiazolinato ligand: X-ray studies, spectroscopic characterization and DFT calculations. Polyhedron, 27, 1679-1689. doi:10.1016/j.poly.2008.02.018

[14] Machura, B., Kruszynski, R., Jaworska. M and Lodowski, P. (2005) Reactivity of [ReOX3(PPh3)2] complexes towards 1,4-diaminobenzene: X-ray structure and DFT calculations. Polyhydedron, 24, 1454-1460. doi:10.1016/j.poly.2005.03.094

[15] Giglio, J., Rey, A., Cerecetto, H., Pirmettis, I., Papadopoulos, M., León. E., Monge. A., López de Ceráin. A., Azqueta. A., González, M., Fernández, M., Paolino, A. and León. A (2006) Design and evaluation of " $3+1$ " 
mixed ligand oxorhenium and oxotechnetium complexes bearing a nitroaromatic group with potential application in nuclear medicine oncology. European Journal of Medicinal Chemistry, 41, 1144-1152. doi:10.1016/j.ejmech.2006.05.006

[16] Machura, B., Kruszynski, R. and Kusz., J. (2007) Polyhedron, 26, 1590-1596. doi:10.1016/j.poly.2006.11.034

[17] Yatirajam .V. and Lakshmi Kantan .M. (2001) Synthesis and characterization of $\mathrm{ReOCl} 3(\mathrm{DTO}) 2$ and $\mathrm{ReOCl} 3$ (MBT)2 complexes, Polyhedron, 2, 1199-1200. doi:10.1016/j.poly.2006.11.034

[18] References and further reading may be available for this article. To view references and further reading y

[19] Pelecanou. M., Pirmettis. I.C., Nock. B.A., Papadopoulos. M., Chiotellis. E. and Stassinopoulou C.I. (1998) Interaction of $[\mathrm{ReO}(\mathrm{SNS})(\mathrm{S})]$ and $[99 \mathrm{mTcO}(\mathrm{SNS})(\mathrm{S})]$ mixed ligand complexes with glutathione: Isolation and characterization of the product. Inorganica Chimica Acta,
281, 148-152. doi:10.1016/S0020-1693(98)00159-5

[20] Machura., B. (2005) Structural and spectroscopic properties of dinuclear rhenium complexes containing $(\mathrm{ReO})$ 2( $\mu-\mathrm{O})$ core. Coordination Chemistry Reviews, 249, 591612. doi:10.1016/j.ccr.2004.07.007

[21] Machura, B., Penczek, R., Kruszynski, (2007) Reactivity of [ReOX3(PPh3)2] complexes towards pyridazine. Xray structures of $[\{\mathrm{ReOCl} 2\} 2(\mu-\mathrm{O})(\mu-\mathrm{pyd}) 2] \cdot \mathrm{C} 6 \mathrm{H} 6$ and $[\{\operatorname{ReOBr} 2\} 2(\mu-\mathrm{O})(\mu-\mathrm{pyd}) 2] \cdot \mathrm{CH} 3 \mathrm{CN}$, and DFT calculations for [\{ReOCl $\} 2(\mu-\mathrm{O})(\mu-\mathrm{pyd}) 2]$. Polyhedron, 26, 3054-3062. doi:10.1016/j.poly.2007.02.019

[22] Braband, H., Miroslavov, A.E., Lumpov, A.A., Sidorenko, G.V, Levitskaya, E.M,. Gorshkov, N.I, Suglobov, D.N., Alberto, R,. Gurzhiy, V.V., Krivovichev, S.V and Tananaev, I.G. (2008) Complexes of technetium (I) (99 $\mathrm{Tc}, 99 \mathrm{mTc})$ pentacarbonyl core with $\pi$-acceptor ligands (tert-butyl isocyanide and triphenylphosphine). Journal of Organometallic Chemistry, 693, 4-10. 